
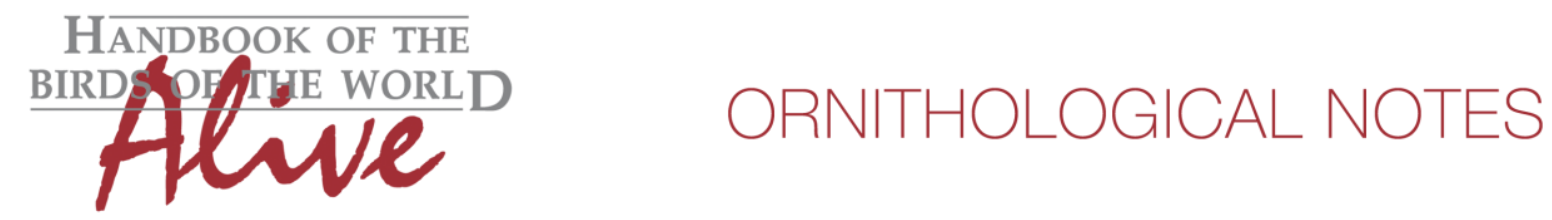

\title{
Notes on the vocalizations of Paltry Tyrannulet (Zimmerius vilissimus) and Venezuelan Tyrannulet (Zimmerius improbus)
}

Peter Boesman

In the following we briefly analyze and compare voice of the different races of Paltry Tyrannulet (Zimmerius vilissimus) and Venezuelan Tyrannulet (Zimmerius improbus). We also try to quantify the extent of any vocal differences using the criteria proposed by Tobias et al. (2010), as a support for taxonomic review.

We have made use of sound recordings available on-line from Xeno Canto (XC), Macaulay Library (ML), Avian Vocalizations Center (AVoCet) and The Internet Bird Collection (IBC).

Of the 5 taxa treated in this case, there were (until now) apparently no recordings available online of dawn song, despite being a fairly common bird in many areas. On a recent trip to Panama, I recorded several times a typical Zimmerius dawn-song which I attributed to Z. v. parvus as it is the only member of this genus occurring there. These recordings were made on three frequently visited places (XC271697, XC271694, XC271699), which makes us believe that this vocalisation is simply under-recorded (coming from the canopy at dawn), and it is quite likely that all taxa of this case have such a dawn song.

As mentioned for the 'Golden-faced Tyrannulet Z. chrysops group', dawn song is similar for several members of the genus (Boesman 2016). This seems thus to be the case for at least $Z$. $v$. parvus as well, and dawn song is maybe not the best vocalization to measure the extent of vocal differences (even if sufficient recordings would be available).

We will therefore compare the 'day-time song', which all Zimmerius members seem to have, and which in the case of Golden-faced Tyrannulet Z. chrysops and Slender-footed Tyrannulet $Z$. gracilipes has been the main driver for some taxonomic authorities to elevate several taxa to species level.

Day-time song (or call) is a simple single note repeated at intervals (Fig 1).

Z. v. vilissimus (S Mexico (Chiapas), S Guatemala and W El Salvador; also numerous sight records from Belize)( $n=5)$ Typical day-time call is a short down-slurred whistle

$\begin{array}{ll}\text { note length } & 0.08-0.17 \mathrm{~s} \\ \text { max. freq. } & 2900-3370 \mathrm{~Hz} \\ \text { min. freq. } & 1800-2100 \mathrm{~Hz} \\ \text { start - end freq. } & 200-1200 \mathrm{~Hz}\end{array}$

Z. v. parvus (Honduras and E Nicaragua S to Panama and extreme NW Colombia (NW Chocó)) ( $n=9$ ) Typical day-time call is a medium-long mellow flat whistle, very often with an upward inflection at the end.

$\begin{array}{ll}\text { note length } & 0.20-0.29 \mathrm{~s} \\ \text { max. freq. } & 3100-3500 \mathrm{~Hz} \\ \text { min. freq. } & 2050-2750 \mathrm{~Hz} \\ \text { start - end freq. } & -300 \text { to } 0 \mathrm{~Hz}\end{array}$

(ML108828 from Darien is more like vilissimus, this may be an atypical call if ID is correct) 


\section{HANDBOOK OF THE \\ BIRDSPF,THE WORLD \\ Alve}

\section{ORNITHOLOGICAL NOTES}

Z. i. petersi (N Venezuela from S Lara E to Miranda) $(n=6)$

Typical day-time call is a long downslurred plaintive whistle (after sharp initial rise), sometimes given in pairs.

$\begin{array}{ll}\text { note length } & 0.75-1.19 \mathrm{~s} \\ \text { max. freq. } & 3400-3700 \mathrm{~Hz} \\ \text { min. freq. } & 2400-2700 \mathrm{~Hz} \\ \text { start - end freq. } & 600-950 \mathrm{~Hz}\end{array}$

Z. i. improbus (N Colombia (Norte de Santander) and NW Venezuela (Táchira, Mérida, Barinas))( $\mathrm{n}=2$ )

Z. i. tamae (N Colombia (Santa Marta Mts) and W Venezuela (Sierra de Perijá and Paramo de Tamá, in Táchira)) A long slightly overslurred whistle, sometimes given in pairs

$\begin{array}{ll}\text { note length } & 0.430 .83 \mathrm{~s} \\ \text { max. freq. } & 3000-3300 \mathrm{~Hz} \\ \text { min. freq. } & 2350-2600 \mathrm{~Hz} \\ \text { start - end freq. } & -200 \text { to } 0 \mathrm{~Hz}\end{array}$
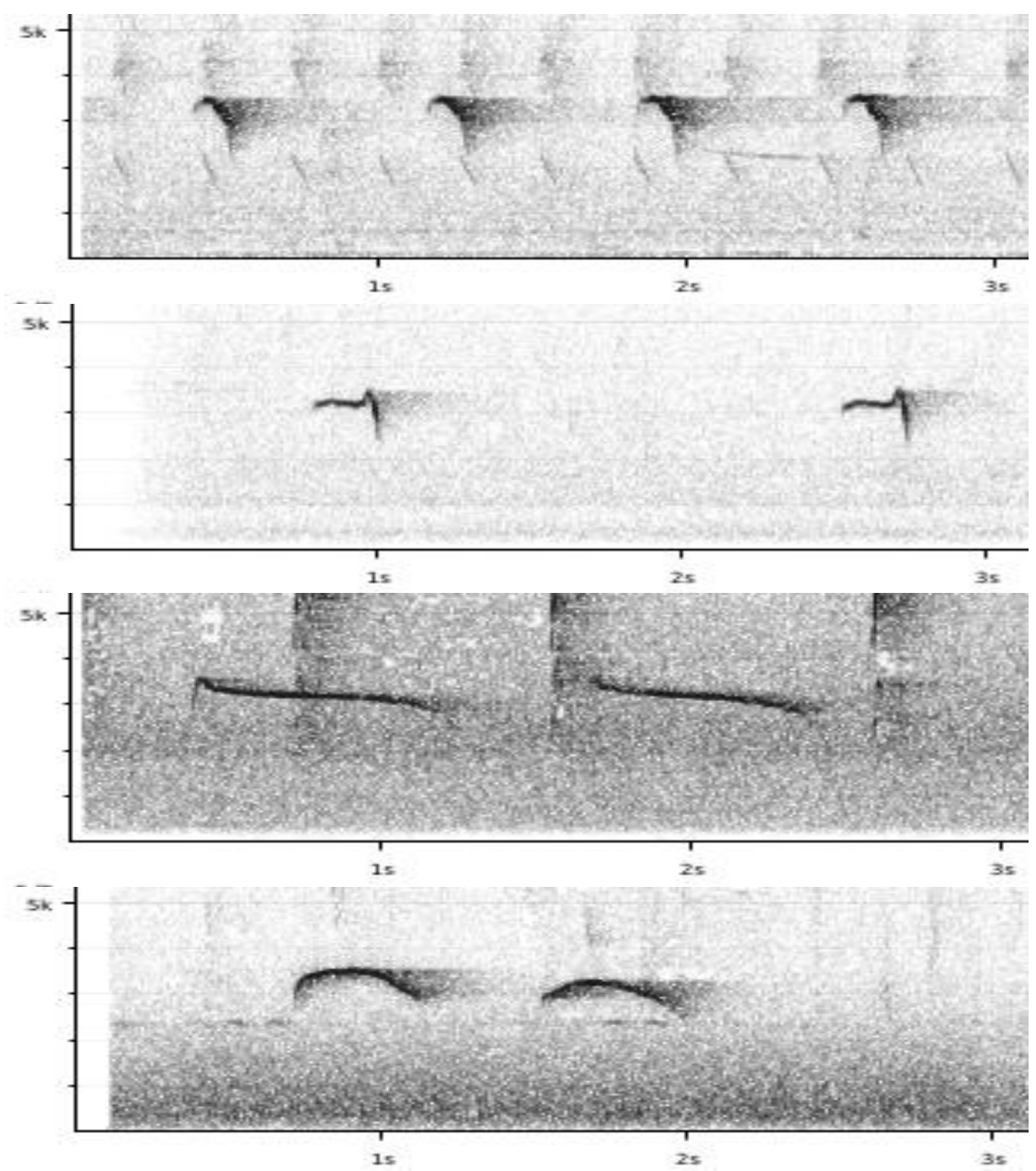

Figure 1: from top to bottom: typical day-time call of vilissimus, parvus, petersi and improbus 

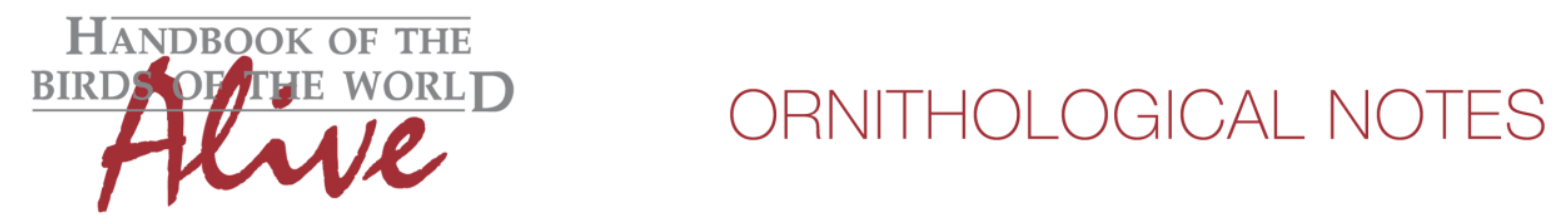

The typical 'day-time song' of all races can easily be distinguished by ear, and is also easily separated by the parameters 'note duration', 'minimum frequency', 'frequency drop/rise' and furthermore note shape:

Z. v. vilissimus (vs. parvus) has the shortest note length (score 2-3), reaches the lowest frequencies (score 1), and the highest frequency drop (score 2) with downslurred note shape (score 1). When applying Tobias criteria, this results in a total vocal score of 4-5.

petersi vs. parvus: Notes are very different, the former having a much longer note length (score 34), no frequency drop (due to initial sharp rise, score 1) and different note shape (score 1). Total vocal score about 5.

petersi vs. improbus/tamae

Despite the fact that we have only located 2 recordings of improbus, we can tentatively conclude that day-time song is closest to petersi, but lacks the gradual frequency drop (score 2) and notelength is slightly shorter (1). Total vocal score about 3.

This note was finalized on 27 th June 2015 , using sound recordings available on-line at that moment. We would like to thank in particular the many sound recordists who placed their recordings for these species on XC and ML.

\section{References}

Boesman, P. (2016). Notes on the vocalizations of Golden-faced Tyrannulet (Zimmerius vilissimus). HBW Alive Ornithological Note 128. In: Handbook of the Birds of the World Alive. Lynx Edicions, Barcelona. (retrieved from http://www.hbw.com/node/932050 on 5 August 2016).

Tobias, J.A., Seddon, N., Spottiswoode, C.N., Pilgrim, J.D., Fishpool, L.D.C. \& Collar, N.J. (2010). Quantitative criteria for species delimitation. Ibis 152(4): 724-746.

\section{Recommended citation}

Boesman, P. (2016). Notes on the vocalizations of Paltry Tyrannulet (Zimmerius vilissimus) and Venezuelan Tyrannulet (Zimmerius improbus). HBW Alive Ornithological Note 127. In: Handbook of the Birds of the World Alive. Lynx Edicions, Barcelona. (retrieved from http://www.hbw.com/node/932050 on 5 August 2016). 